\title{
Learning in later life: A bi-cultural perspective from Aotearoa/New Zealand
}

This article is concerned with how learning in later life has been constructed and practised by the two most numerous ethnic groups in Aotearoa New Zealand, Pākèha (Europeans) and Māori (indigenous people). The term “Aotearoa/New Zealand” is used in this paper to signify the dual cultural heritage upon which the country has been established. It is argued that learning is heavily influenced by historic features of interaction between these two groups; Pākehā as the dominant cultural and economic group and Māori as subordinate, or in Freirean terms (1984), as oppressors and oppressed respectively. Yet while contemporary perspectives are necessarily interpreted in the light of social structure and history (Mills, 1959), fresh interpretations of what constitutes bi-culturalism in this country allow for more nuanced understanding of possibilities for and obstacles to older adult learning/education. Further, given the foregrounding of bi-culturalism, in preference to multi-culturalism, in much of education and social policy, it is not surprising that principles emanating from this traditional relationship are continually contested by colonisers and colonised alike (Smith, 2012).

The argument for this article is initially broad in discussing what it means to be Māori and Pākehā in a bi-cultural context, influenced by historical trends and events, especially the founding document of the Treaty of Waitangi. Next follows a depiction of Māori sovereignty and pedagogy before focussing on the character of older people, both Māori and Pākehā, in contemporary New Zealand. Themes from lifelong learning are analysed with special reference to older people's learning and trends identified for older adult education. A case study of Pākehā and Māori older adult education in a New Zealand university are described to illustrate complexities and tensions in provision in a bi-cultural context. Finally, observations of what this means for older learners in the bi-cultural context of Aotearoa New Zealand are provided.

\section{An historical context: patterns of dominance}

While it is freely acknowledged that Māori are the original people of this land (tangatawhenua) and that Europeans in several waves of interaction with the indigenous people colonized the country in the 18th century to the present (arguably, the country continues to be colonized), the level of autonomy achieved by Māori as an indigenous people is considerable by international standards. The Māori themselves, believed to have arrived in Aotearoa in seven waka (canoes) from Hawaiki but not necessarily in unison, settled in different geographical parts of the country and laid claim to this land as a spiritual taonga (treasure). Hence, the arrival of whalers, missionaries and eventually settlers resulted in varied forms of responses from iwi (tribes), including warfare and trade. Yet perhaps the most powerful strategy from Pākehā emerged from the bible in translation, especially as hegemony was established through the written word for a language that was traditionally oral. As Gramsci (1971) might conclude, conquest (at least partial conquest, given the active resistance from Māori) was mainly achieved through peaceful means amid sporadic counter-hegemonic responses from Māori. 
In a reduced explanation, the dominant patterns of interaction and citizenship, as forerunners to current bi-culturalism, could be described as conversion, assimilation and integration (Pearson, 2005). The conversion phase included an imposition of a Pākehā world view upon the indigenous people; an assimilationist mode of interaction entailed convincing Māori to behave like the European, in effect, to "become like us"; an integration mode involved the combining of both cultures but in practice often meant Māori relinquished autonomy to Pākehā. Education policy tended to echo these tendencies. For instance, the introduction of taha Māori in schools in the 1970s by the then Education Department was an attempt to sensitize European children to Māoritanga (things Māori) but became an embarrassment to both parties as Māori life was over-simplified and trivialised as "Māori culture", mainly in displays of artefacts and the learning of waiata (Māori songs) (Smith, G., 1990; Smith, L., 2012).

More recent times have involved a more complex array of interactions and associated educational formations. Some of the "old" ways of interaction still survive and associated stereotypes prevail. However, the initiative conceived by Māori to rescue the decline of te reo (Māori language) and re-assert tino rangatiratanga (sovereignty) was to establish kohanga reo (language nests) in which the native language was the norm and customs and practices of Māori were given highest priority. The success of this venture was rather unexpected by Government which initially watched from the side and did not provide public funds (McCarthy, 1996); however, eventually, the Government agreed to fund these early childhood centres and the consequent developments in primary and secondary schools, kura kaupapa Māori, and three tertiary education institutions controlled by Māori for Māori, whare wānānga. Hence, in very tangible form, Māori self-determination became manifested in a structured lifelong learning framework, in addition to more informal learning.

\section{The Treaty of Waitangi and bi-culturalism}

The Treaty of Waitangi, signed in 1840 between the British Crown and Māori (more accurately, the mainly Northern iwi (tribes) of Aotearoa), signalled a mutual commitment to live alongside each other. Three versions of the Treaty emerged (the English; the Māori; the English translation of the Māori version), thus triggering multiple interpretations of specific articles within the document. Depending on one's positionality, principles from the Treaty tended to favour one party or the other. Hence, power differentials between Pākehā and Māori need to be acknowledged (Bishop \& Berryman, 2002). While the arguments will no doubt continue, at least three principles have emerged to guide relationships between the indigenous people and the colonizers. These principles, often espoused in official Government policies, are protection (of te reo, Māori language, and the land), partnership (as in agreeing to work together concerning the use of natural and social resources) and participation. This last-mentioned category emanates from the realisation that in mainstream New Zealand society, Māori have been dubbed "under-achievers" or "historically disadvantaged” in social policy and practices. For instance, in education, statistics reveal that Māori have not achieved in comparison with the Pākehā norm. Greater encouragement of Māori for active engagement in education, as in the award of scholarships in higher education, is perceived to be an enactment of social equity. In the wider country-wide scene, social 
equity related specifically to Māori operates in education, health, social welfare and other domains to help readdress historic disenfranchisement.

What does this have to do with bi-culturalism? Once the special relationship between the tangata whenua (original people of the land) and the Crown is accepted in official discourse, it becomes the core of a bi-cultural perspective in New Zealand. Yet, official statistics reveal a complex array of ethnic groups now living in this country. The latest 2013 census identifies an increasingly diverse population, as new immigrants, especially from Asian countries, have found this geographically remote country a good place in which to live and/or invest. The respective percentages of ethnic groups are as follows: European 74\%; Māori 14.9\%; Pacific Peoples 7.4\%; Asian 11.8\%; Middle Eastern, Latin American, African 1.2\% and other 1.7\% (Statistics New Zealand, 2003). This pattern, at a superficial level, represents ethnic pluralism and it suggests an argument for multi-culturalism rather than bi-culturalism. A multi-cultural perspective is likely to entail a recognition of all ethnic groups in New Zealand, with no single ethnic group having special significance. To some extent, there is support, particularly from Pākehā, for viewing New Zealand as a multi-cultural country, given that migration will continue unabated and cultural diversity flourish. Yet to do so, undermines the historic special relationship of bi-culturalism emerging from the Treaty. For most Māori, multiculturalism is a sop to a bi-cultural approach in which the longstanding Pākehā-Māori relationship is not given sufficient credence (Smith, 2012). The tensions of this argument are well encapsulated by May (2004, p.251):

This clearly observable tension between biculturalism and multiculturalism is not easily resolved, not least because the crucial issue for Māori, and for indigenous peoples more broadly, is one of differing entitlement. As an indigenous people, Māori argue that they have a distinct, and greater claim to representation in the public realm than do migrant minority groups.

In short, bi-culturalism in this context refers to the relationship between Pākehā and Māori. It is a subset of a more general pattern of dominance typical of colonizers-colonized in which there is a dominant and subordinate group where an unequal power relationship exists (Spoonley, Macpherson \& Pearson, 2004). Such a view does not obscure the reality that there is considerable within group diversity: in Māori society, iwi (tribes) have their own distinctiveness and more often than not, Māori themselves refer to their primary identity as an iwi member, not via the generic term of Māori. For Pākehā too, there is tremendous diversity related to respective waves of immigration, mainly from Europe.

\section{Māori society, sovereignty and pedagogy}

The brief history of Māori provided above has signalled the historic suppression of Māori language and culture. Schools as agents of social control have mainly functioned according to European structures, "rules” and processes. However, in the early 1980s the revitalisation of te reo became really important to Māori as their identity was threatened by the then corrosion of the language. Under the principle of tino rangtiratanga (self-determination) Māori took the initiative themselves to resurrect the language and in so doing, created a parallel 
education "programme" in which Māori language and customs would be paramount. Collectively, iwi throughout the country established kohanga reo (language nests) where Māori parents and grandparents (kaumātua) took leadership of this impetus. Kohanga reo required the rapid investment of Māori voluntary labour and the training of Māori language speakers and educators. The establishment of this new early childhood institution triggered further creations of culturally appropriate education structures for children of an older age in the form of kura kaupapa Māori schools (primary and secondary education). Eventually, the demands of these large cohorts of young adults resulted in the creation of three whare wānanga (Māori tertiary education providers) in which kaupapa Māori (Māori philosophy and values) was given precedence.

This new parallel system is open to all learners, not only Māori, but in practice the vast majority of students are Māori (TEC...). This structure incorporating early childhood to late adulthood embodies the concept of lifelong learning. While this system usually involves more formal learning opportunities, there are also non-formal and informal possibilities too. A key feature of this alternative system to the mainstream is the control of knowledge construction and dissemination by Māori for Māori; a Māori world view has ascendency. In this environment, older Māori are integrated into the learning system and frequently act as role models, especially in traditional contexts such as on a marae (communal meeting place).

At a somewhat surficial level the different interests of Māori and Pākehā can be summarized in Figure 1.0. In effect, this table illustrates the pattern of dominance-subordination derived from a history of colonization. Pākehā interests are usually considered normative; Māori as deviant. Nevertheless, in contemporary New Zealand society, the values and some practices of Māori have been incorporated into daily life exemplified by public occasions often beginning with a mihi (greeting) and karakia (prayer).

Figure 1.0 Pākehā and Māori Interests

\section{Pakeha Interests}

Pakeha culture, language,

Knowledge

Acculturation, assimilation

"We are one people"

Domination

Maintain status quo

\section{Māori Interests}

Māori culture, language,

knowledge

Validity and legitimacy

of Māori

"We are Māori"

Survival

Work for change

Source: Jones et al (1995, p.195) 
While arguably this is a simplistic portrayal of the different major orientations of the respective dominant and subordinate groups - given that there is considerable variation within the groups - it does provide a snapshot of different paradigms and valuing of what counts as knowledge (Young, 1971).

The holistic perspective to lifelong learning has been emphasized by theorists such as Graham Hingangaroa Smith (2000, pp.66-68). The kaupapa Māori approach stresses multiple dimensions of human life and is integrated into learning processes. He identifies the following cultural dimensions to Māori learning as significant in establishing principles for intervention:

- The principle of self-determination or relative autonomy. Māori need increased control over their lives and their cultural well-being. This should result in better buyin and commitment by Māori participants in education.

- The principle of validating and legitimizing cultural aspirations and identity. In Kura kaupapa Māori (Māori schools) being Māori is taken-for-granted; importantly, a strong emotional and spiritual dimension is incorporated into indigenous people's experiences.

- The principle of incorporating culturally preferred pedagogy. Teaching and learning practices are connected closely with cultural backgrounds and life circumstances.

- The principle of mediating socio-economic and home difficulties. Māori communities need to take seriously the schooling/education enterprise. Acknowledgment of difficulties is felt at an ideological level and this realisation should assist in mediating a societal context of unequal power relations.

- The principle of incorporating cultural structures that emphasize collectivity rather than individuality such as the notion of the extended family. The total whānau (extended family and networks) take collective responsibility; they need to reinvest in schooling/education as a normal collective expectation.

- The principle of a shared and collective vision and philosophy. Such a vision provides guidelines for excellence (what a "good” Māori education should look like); a “critical pedagogy” is advocated.

Smith maintains that all these principles should be upheld simultaneously and are of equal value to one another. Indeed, "Māori experience suggests that these elements may occur in any order and may occur simultaneously” (2000, p.69). This framework from Graham Smith as a Māori critical theorist is somewhat derivative of a Freirean approach to teaching-learning and provides an understanding of how political-cultural-economic dynamics play out in the lives of Māori.

In the next section, background on older adulthood is provided before discussion of case studies from each of Māori and Pākehā contexts to illustrate characteristics of their respective cultures in later life learning. 


\section{Older adults in New Zealand}

As is quite common amid Western countries, the proportion of the older population beyond 65 years is increasing due to lower fertility rates among the young and better health care and technological advances for the care of seniors (Phillipson, 1998). New Zealand is no exception. The 2013 census shows that the age structure is maturing towards an ageing society (Statistics New Zealand, 2003). In 2013 people aged 65 years constituted 14.3\% compared with $12.1 \%$ in 2001. Among Māori and Pasifika, a more youthful population is in evidence. According to Dunstan and Thomson (2006), the normative life expectancy of the New Zealand male is 77 (expected to rise to 83.5 by mid-century) and 81.6 for females (expected to rise to 87.0 in a similar timeframe); for Māori, life expectancy is 72.0 for males (expected to rise to 76.3 by 2021) and 73.2 for females (expected to rise to 80.3 by 2021). Proportionately, fewer Māori survive into late adulthood (defined as $85+$ ). The number of people aged 65 and over has doubled since 1970 and the growth in this age group will account for $87 \%$ of the growth in the total population between 2005 and mid-century. These same demographers identify that while the 65 and over population is projected to increase for European, Māori, Pasifika and Asian alike, among Europeans it is anticipated that the relative proportion will be $22 \%$ and $7 \%$ for Māori. Hence, the life expectancy trajectories of these two different ethnic groups suggest different life chances and responses to ageing processes.

So, who are older adults in this country? Despite the depiction above from statistics, chronological age is a crude indicator of older adulthood and indeed, what constitutes "older age” is problematic (Phillipson, 2013). Certainly, given the heterogeneity of older people and their life experiences, it is foolhardy to future gaze beyond empirical evidence available through analysis of societal trends (for example, seniors' use of health care). Legal and policy definitions do provide some guidance, linked as they are to key transitions in the life-course such as the award of a pension; in New Zealand at 65 there is a universal Government pension (Findsen, 2014). Ultimately, the notion of an "older adult" is context specific and culturally defined. For the purposes of this article, older adulthood is presumed to commence at age 65 and "old-old" at age 85 but these benchmarks are contestable.

\section{Learning in later life}

\section{(i) Discourses from lifelong learning}

The language surrounding lifelong learning, in which later life learning itself is located, is related to four observable themes internationally and locally. For both Pākehā and Māori, these themes have resonance in their daily lives and participation in learning/education is contextualized according to these imperatives. According to Findsen and Formosa (2011), the four categories within which later life learning for older adults can be understood are as follows:

The economic dimension: New Zealand, as for other nations, seeks to optimize its labour force by upskilling individuals, exhorting organizations to compete internationally for markets, and promoting an entrepreneurial spirit at a national level. Workers, including older adults, are expected to adjust to the new world of work and, as necessary, acquire new 
knowledge, especially related to ICT (Rothwell, Sterns, Spokus \& Reaser, 2008), and to provide greater effectiveness in work contexts. If required, they may need to return to formal study to obtain credentials to retain their current employment or to be more competitive in securing a new work role (Findsen \& McCullough, 2008). Governmental policy in adult and continuing education tends to favour young people (Jesson, 2012) and largely renders older people as invisible. Yet increasing numbers of older people, either through coercion or choice, need to stay in the job market for longer periods of their lives (Lundberg \& Marshallsay, 2007).

Personal fulfilment: This theme emphasizes that in the third age (Laslett, 1989), many older adults have increased leisure and the potential for creativity in a phase of "retirement". Historically, this discourse has been located in the liberal adult education tradition often associated with adult/continuing education based in universities. It is a theme that accentuates learning for its own sake and where the learning process has intrinsic value unrelated to predetermined outcomes. The theme is predicated on an ideology of individualism and is humanistically-oriented (Knowles, 1984).

Some of the dominant ideas linked to this discourse are located in the self-directed, informal learning sphere (Brookfield, 1986; Jarvis, 2001). Much valued learning is experientiallybased and individuals are encouraged to develop their own pathways of learning. While this viewpoint has high credibility among the èlite of societies, including in New Zealand, the realities emergent from social stratification in social class, ethnicity, gender and geographical location tend to influence who gets what forms of knowledge among elders (Findsen, 2005).

Active citizenship: A third distinctive theme of lifelong learning applied to older adulthood is that of developing an active citizenry. An active citizen is one who is self-aware, cognisant of societal issues and acts proactively in a civil society (Welton, 2005). In a democratic context which New Zealand purports to support, older adults, especially through volunteering, can provide service to others and contribute positively to the wider development of society.

Away from the more overt influence of the market and the state, older people can function in civil society to develop civil, social and political citizenship. As pointed out by Coare and Johnston (2003), active citizenship can help older citizens to develop greater reflexivity, to critique the prevailing idea of the "economic citizen" and to challenge knowledge bestowed by experts on the masses.

Social inclusion/exclusion: The fourth theme from lifelong learning applicable to older adults, relates to social inclusion. Just as higher education in many countries has been engaged in "widening participation" (Layer, 2005; Thompson, 2000) to encourage "nontraditional" students to enter the institution (including older people as a typical category), the wider society has sought to include older people into the mainstream such as their inclusion within age-friendly cities (Longworth, 1999). Some groups of people have been excluded from educational opportunities in earlier life by dint of social class, gender, race/ethnicity, geographical location and so on. Their location in an economically stratified society has usually influenced their life chances and real choice in learning/education. This is certainly the situation of many Māori. Whether in the workplace or another public location, one's 
economic and cultural capital (Bourdieu, 1974) has a heavy influence in one's deciding what might be appropriate later life learning. For instance, the well-known institution and social movement of the University of the Third Age (U3A) has a strong white-middle class (predominantly female) membership reflective of the liberal education curriculum and social networks of Pākehā society. Social exclusion for Māori is a reality in formal education (as in universities) and in less formal social institutions such as the U3A (Findsen, 2006).

\section{(ii) Trends in older adult education in Aotearoa/New Zealand}

New Zealand has tended to follow trends from Western countries, especially in relation to Pākehā learning engagement in later life. As identified by Dakin (1992), the dominant education institutions have largely replicated those of the UK, as exemplified by the Workers' Education Association (WEAs) and early university extension (later converted to centres for continuing education). However, he also points out that in addition to these derivative institutions, there are very worthwhile innovative indigenous institutions such as Te Ataarangi, a Māori language programme based on developing oral facility in te reo (Māori language) as opposed to more traditional methods of reading and translating Māori language from written texts.

Trends of New Zealand-based older adult education include an increasing blending of expressive and instrumental learning, thus acknowledging that motives for learning can be multiple and ever-changing (O’Connor, 1987). Clearly, older people engage in both forms on a daily basis. The diversity of provision in adult education more generally allows for older people to be engaged in learning with mixed aged participants (inter-generational learning) while there are some providers such as Seniornet (a peer learning group of seniors working with seniors to enhance ICT knowledge and skills) whose clientele is demonstratively older people in an age-segregated environment. Most learning for seniors is via non-formal education or informal daily activities (Jarvis, 2001); formal education is technically open to seniors but often barriers have been erected (usually inadvertently) by agencies which minimises their participation. As a case in point, higher education institutions have made feeble attempts to recruit this cohort (Duke, 2005). In both Māori and Pākehā contexts, especially as baby-boomers as a cohort enter this age group, there is a strong desire to be selfreliant and to determine for themselves what is "really useful knowledge". Participation patterns in more formalized education for seniors tends to mirror the patterns in earlier life, that is, those who have already, tend to get more (Findsen, 2005). In addition, it is wise to consider the considerable extent of elders' voluntary labour propping up many social services (e.g. St Vincent de Paul) wherein older adults donate their expertise and time, in this instance, along peer support lines (Milligan \& Conradson, 2006).

\section{Case studies of Māori and Pākehā older adult education provision}

The following case studies, one from each ethnic group (Pākehā and Māori), illustrates the character and issues faced in organizing learning for and with seniors in this bi-cultural context. The Pākehā case relates to continuing education provision, at the time based in the Centre for Continuing Education (CCE) at the University of Waikato; the Māori case is 
located in the Rauawaawa Charitable Trust, a multi-faceted agency which focuses on the diverse needs of kaumātua (Māori elders) in Hamilton city. The two cases are inter-linked and are related to the wider policy framework for adult education in New Zealand and, more particularly, the Tertiary Education Commission's (TEC's) criteria for Adult and Community Education (ACE) provision within a University context. Hence, a brief historical overview is provided to elucidate this relationship.

Background: The CCE at the University of Waikato was established in the mid-1970s and quickly developed an excellent reputation for outreach into the regions of the University plus a dynamic provision within the city of Hamilton. Arguably, its most notable achievements were the innovations in Māori education, women's studies and trade union work (all originally marginalized areas of study). In the case of the first-mentioned, a successful Certificate in Māori Studies operated for many years wherein both Māori and Pākehā could learn te reo from an introductory level and acquire a University qualification. Perversely, many already fluent speakers of te reo enrolled to gain a qualification to substantiate their credibility as language teachers to their own people.

Into the 2000s, the context for ACE had changed dramatically in accord with pervading neoliberal exigencies, especially the call for heightened accountability and quality assurance. The CCE was expected by the University under the surveillance of the TEC (the Government's funding body for tertiary education, including much of ACE) to reach an historically established pre-determined quota of Equivalent Full-Time students (EFTs). The funding priorities for ACE in universities were set as follows:

1. Provide specialised and research-informed higher level learning that contributes directly to the creation of an advanced and rapidly evolving knowledge economy;

2. Contribute to the knowledge society through the preservation, dissemination and application of university research;

3. Promote the development of critical and reflective thinking, the active and informed citizenship locally, nationally and globally;

4. Facilitate pathways into and through university education;

5. Build capability in the wider ACE sector (while having regard to the ACE professional development strategy).

These priorities were for universities only. Outside this context, the wider ACE funding criteria were:

1. Targeting learners whose initial learning was not successful;

2. Raising foundation skills;

3. Strengthening social cohesion.

It is fair to assert that there was contestation for the CCE between the more generalised priorities and those for the universities in particular. However, these TEC priorities set the economic and pedagogical context for the support to the Rauawaawa Trust with whom the CCE had a memorandum of agreement (MoA). 
In 2011 the Government cut funding to university ACE by $48 \%$ and finished the task the following year by taking away all funding. As a consequence, the University decided to close the CCE at the end of 2012.

\section{Pākehā Case study: The 60 plus groups}

As part of the CCE's total provision, it had worked alongside eight groups from regional towns, including the city of Tauranga, to help the local groups of older people, all of whom were volunteers, to conduct a viable programme in continuing education of relevance to the local communities. The resourcing from the CCE to these groups was modest, consisting of a small annual grant and support for professional development. In practice, this usually meant a day at the CCE where representatives from the groups could discuss achievements, problems and network with one another.

In addition to the smaller town 60+ groups, the Hamilton version gained momentum and has continued beyond the closure of the CCE. Hence, it is only loosely connected with the University. In many ways, this provision mirrors that of the U3A movement. As identified by Swindell (1999) and Formosa (2000), the U3A is characterized by informality, a curriculum devised by local people but often strongly linked to liberal education, is democratically run, has low fees to encourage maximum participation and uses peer learning. "Experts" frequently emerge from the group and share their knowledge in a non-threatening way. The Hamilton 60+ group manifests most of these behaviours but is more traditional in terms of its practice. Usually, the format consists of a guest invited from outside the target group of 200300 people to present on a specialist topic, sometimes associated with research, particularly if the person is from the nearby University.

The critique of the U3As is also applicable to these groups of 60+ adults. Essentially, these are Pākehā-driven organizations where the curriculum reflects their cultural interests. Those outside this norm find it difficult to participate as their social capital (Field, 2003) has been developed in another milieu. Hence, while ostensibly these are "open systems” for learning, in practice familiarity with mainstream culture is taken-for-granted. Predictably, the regional groups have found it difficult to sustain themselves; in the city, a critical mass of Pākehā with sufficient know-how has pooled collective knowledge to maintain the programme. Hence, fortunately, the programme continues today.

\section{Māori case study: the Rauawaawa Trust}

The Rauawaawa Trust is a holistically-oriented Māori-controlled organization that is geared to support kaumatua well-being, including their learning needs (Thompson \& Barrett, 2007). The relationship with the CCE was formalized in 2004 and continued until the CCE itself was closed. Under the MoA, the funding for the programme came from the TEC to the University to the CCE and then to the Trust. The Trust was the employer of teachers, selected from within the agency (akin to Gramsci's organic intellectuals), the provider of the learning environment and record keeper of enrolments. In pedagogical terms, the curriculum was developed in collaboration with the CCE (while acknowledging the TEC's priorities) but was certainly heavily weighted towards a kaupapa Māori agenda. Most of the teachers had 
University-level credentials and the focus of courses was on developing and sustaining capacity-building amid local iwi, primarily Tainui. The social and cultural capital of adherents was a core component and the curriculum was built on this assumption. Actual courses included te reo, waiata (songs), healthy eating, cloak-making, speech-making (for men), basket-making (for women) and other culturally suitable programmes. These activities were carried out in an older adults' setting where cultural embarrassment could be minimized and appropriate spiritual elements introduced (Smith, 2000). The essential point here is that this was (and still is) a peer learning environment where the well-being of elders is given precedence, as opposed to the direction of many Government-funded projects which are aimed at rangatahi (youth).

The partnership between the two parties was unique in Aotearoa New Zealand. The current TEC priorities identify under 25s, Māori and Pasifika students as of primary importance (TEC, 2012). While all eight universities in this country have relationships with local iwi, the concentration on kaumātua was idiosyncratic. The pedagogy employed was derivative of that espoused by Smith (2012) as well as Bishop and Berryman (2006). The notion of engendering leadership among the elders, so important to the efficacy of this programme, is part of the overall social movement amid Māori for self-determination and autonomy. Refreshingly, the programme has not been overtly channelled towards developing Māori entrepreneurs according to a neo-liberal agenda but focussed on more holistic community development where the aspirations and needs of seniors take priority.

\section{Concluding remarks}

This article traversed the overall relationship of colonizer and colonized in the particular context of Aotearoa New Zealand. This dominant-subordinate relationship between Pākehā and Māori has permeated interactions across these major ethnic cultures and set a trajectory for educational policies and practices. The plight of older adults' learning needs to be contextualised in this wider socio-cultural framework, also influenced in more recent times by a government-led neo-liberal agenda.

Governmental economic rationalism has impacted directly on provision but has not meant the demise of two significant programmes for older adults in Hamilton, one Pākehā, the other Māori. In both cases, the programmes have survived cuts in funding from a less than empathetic government. As observed by Olssen, Codd and O'Neill (2004), the state apparatus is continually being attacked and savings are being made in Government spending in the name of efficiency. While only a small player in the broader realm of education, ACE has suffered dramatic cuts thus jeopardising adult education programmes. The continuance of the programmes has been reliant on voluntary labour and a consciousness of the importance of provision through collective endeavour. In both case study instances, the funding to older adult education was indirect; it is unlikely that any direct financing of older adult education would be countenanced by government, given the TEC's existing priorities. The Trust's education programme fits the criterion of Māori community development but given that older adults are the forgotten sub-population in this country in terms of any formal education 
provision (Findsen \& Formosa, 2011), this initiative's survival depends on sustained engagement of Māori for Māori.

Learning for both ethnic groups continues more plentifully in non-formal education and informal learning contexts. Given historical cultural dynamics within the country and continuing bids for greater self-determination among iwi, the continuing existence of a parallel system based on ethnicity, as outlined above, is a probable scenario for the future. The issue of the control of language and knowledge is paramount for Māori as the subordinate group; the Pākehā majority, in the dominant political, cultural and economic position, does not need to embrace Māori aspirations. Indeed, some Pākehā are oblivious to Māori values and customs, preferring to ignore the indigenous people's calls for greater social justice. The position of Māori elders remains precarious and much of their continuing capacity-building may best be enacted without government support or interference. Yet what the previous agreement between the CCE of the University and the Rauawaawa Trust was able to demonstrate is that while bi-culturalism often gets translated into separate development, there is also mutual benefit possible when co-operation between Māori and Pākehā is directed to some of the country’s most vulnerable citizens. 


\section{References}

Bishop, R. \& Berryman, M. (2006). Culture speaks: Cultural relationships and classroom teaching. Wellington: Huia Publishers.

Brookfield, S.D. (1986). Understanding and facilitating adult learning. San Francisco: Jossey Bass.

Bourdieu, P. (1974). The school as a conservative force. In Eggleston, J. (Ed.) Contemporary research in the sociology of education (pp.32-46). London: Metheuen.

Coare, P. \& Johnson, R. (2003). Adult learning, citizenship and community voices. Leicester: NIACE.

Dakin, J. (1992). Derivative and innovative forms of adult education in Aotearoa New Zealand, New Zealand Journal of Adult Learning, 20, 2, 29-49.

Dunsan, K \& Thomson, N. (2006). Demographic Trends. Chapter 2 in Boston, J. \& Davey, J.A. (Eds). Implications of population ageing: opportunities and risks (pp.9-49). Institute of Policy Studies, Victoria University of Wellington,.

Duke, C. (2005). (Ed.) The tertiary moment: What road to inclusive higher education? Leicester: NIACE.

Field, J. (2003). Social capital, London: Routledge.

Findsen, B. (2014). Older adult education in a New Zealand university: Developments and issues. International Journal of Education and Ageing, vol.3, no.3, 211-224.

Findsen, B. (2012). University and community engagement through continuing education: The case of the University of Waikato and the Rauawaawa Trust, in Jones, P., Storan, J. Hudson, A. \& Braham, J. (Eds) Lifelong learning and community development (pp. 43-55). University of East London: Forum for Access and Continuing Education.

Findsen, B. (2006). Social institutions as sites of learning for older adults: Differential opportunities, Journal of Transformative Education, 4, 1, 65-81.

Findsen, B. (2005). Learning later. Malabar, Florida: Krieger Publishing Co.

Findsen, B. \& Formosa, M. (2011). Lifelong learning in later life: A handbook on older adult education. Rotterdam: Sense Publishers.

Findsen, B. \& McCullough, S. (2008). Older adults' engagement with further and higher education in the West of Scotland: Tracking educational journeys. Glasgow: Department of Adult and Continuing Education, University of Glasgow and the West of Scotland Wider Access Forum. Final Report, August. 
Findsen, B. \& Tamarua, L. (2007). Maori concepts of learning and knowledge. In Merriam, S.B. \& Associates, Non-Western perspectives on learning and knowing, (pp.75-97). Malabar, Florida: Krieger Publishing.

Formosa, M. (2000). Older adult education in a Maltese University of the Third Age: A critical perspective. Education and Ageing, 15 (3), 315-339.

Freire, P. (1984). Pedagogy of the oppressed. New York: Continuum.

Gramsci, A. (1971) Selections from the prison notebooks, edited and translated by Quintin Hoare and Geoffrey N. Smith. London: Lawrence \& Wishart.

Jamieson, A. (2007) Higher education study in later life: What is the point? Ageing \& Society, 27, 363-384.

Jarvis, P. (2001) Learning in later life. London: Kogan Page Ltd.

Jesson, J. (2012) Adult and community education. In M. Thrupp. \& R. Irwin, Another decade of New Zealand education policy: Where to now? (pp.131-147). Hamilton, New Zealand: Wilf Malcom Institute of Educational Research.

Jones, A., Marshall, J., Morris-Matthews, K., Smith, G. H. and Smith, L.T. (1995) (2 ${ }^{\text {nd }}$ ed.) Myths and realities: schooling in New Zealand. Palmerston North: The Dunmore Press.

Kelsey, J. (1999) Reclaiming the Future: New Zealand and the Global Economy, Wellington, Bridget Williams Books.

Knowles, M. (1984). Andragogy in action. San Francisco: Jossey Bass.

Laslett, P. (1989). A fresh map of life: The emergence of the third age. London: Weidenfeld \& Nicholson

Layer, G. (2005) (Ed.) Closing the equity gap. Leicester: NIACE.

Longworth, N. (1999). Making lifelong learning work: learning cities for a learning century. London: Kogan Page.

Lundberg, D. \& Marshallsay, Z. (2007). Older workers’ perspectives on training and retention of older workers. Adelaide, South Australia: National Centre for Vocational Education Research \& the Australian Government.

McCarthy, M. (1996). "He Hinaki Tukutuku: the baited trap. Whare wānanga: tensions and contradictions in relation to the State" in J. Benseman, B.Findsen, \& M. Scott, M. (eds), The fourth sector: Adult and community education in Aotearoa New Zealand. (pp.81-94). Palmerston North: The Dunmore Press.

May, S. (2004). Accommodating multiculturalism and biculturalism: implications for language policy. In Spoonley, P., Macpherson, C. \& Pearson, D. (Eds) Tangata tangata: The changing ethnic contours of New Zealand. Southbank, Victoria: Thomson/Dunmore Press, pp.247-264. 
Midwinter, E. (2004). 500 beacons: The U3A story. London: Third Age Press Ltd.

Milligan, C. \& Conradson, D. (2006). (Eds) Landscapes of voluntarism: new spaces in health, welfare and governance. Bristol: The Policy press.

Mills, C.W. (1959). The sociological imagination. London: Oxford University Press.

O’Connor, C.M. (1987). Elders and higher education: Instrumental or expressive goals? Educational Gerontology, 12: 511-519.

Olssen, M., Codd, J. \& O’Neill, A-M. (2004). Education policy: Globalization, citizenship and democracy. London: Sage Publications.

Pearson, D. (2005). Citizenship, identity and belonging: Addressing the mythologies of the unitary nation state in Aotearoa/New Zealand. In Liu, J.H., McCreanor, T., McIntosh, T. \& Teaiwa, T. (Eds.) New Zealand identities: Departures and destinations, (pp.21-37).

Wellington: Victoria University Press.

Phillipson, C. (2013). Ageing. Cambridge, UK: Polity Press.

Phillipson, C. (1998). Reconstructing old age: New agendas in social theory and practice. London: Sage Publications Inc.

Rothwell, W.J., Sterns, H.L., Spokus, D. \& Reaser, J.M. (2008). Working longer: New strategies for managing, training, and retaining older employees. New York: American Management Association.

Scott, D. (2010). Non-formal and formal learning - adults in education. Wellington: Ministry of Education.

Smith, G.H. (2000). Māori Education: Revolution and transformative action, Canadian Journal of Native Education, 24 (1), 57-120.

Smith, G.H. (1990). Taha Māori: Pākehā capture. In Codd, J., Harker, R. \& Nash, R. (Eds.) (2nd. Ed.). Political issues in New Zealand education (pp.183-197), Palmerston North: The Dunmore Press.

Smith, L.T. (2012). Decolonizing methodologies: research and indigenous peoples. London: Zed Books.

Spoonley, P. Macpherson, C. \& Pearson, D. (2004). (Eds.) Tangata tangata: The changing ethnic contours of New Zealand. Victoria, Australia: Thomson/Dunmore Press.

Statistics New Zealand (2013). 2013 Census Quickstats about national highlights. (www. stats.govt.nz). Wellington: New Zealand Government.

Swindell, R. (1999). New directions, opportunities and challenges for New Zealand U3As, New Zealand Journal of Adult learning, 27, 1, 41-57. 
Tertiary Education Commission (TEC). (2012). Priorities for TEIs, at http://www.tec.govt.nz/Funding/Fund-finder/ACE-in-communities/ACE-in-TEIs (accessed 31 May 2012)

Tett, L. (2004). Mature working-class students in an èlite university: Discourses of risk, choice and exclusion, Studies in the Education of Adults, 36, 2, 252-264.

Thomas, L. (2001). Widening participation in post-compulsory education. London: Continuum.

Thompson, J. (2000) (Ed). Stretching the Academy: The Politics and Practice of Widening Participation in Higher Education. Leicester, NIACE.

Thompson, K.A. \& Barnett, A.R. (2007) 'Outcome evaluation of the Centre for Continuing Education’s iwi and Māori community initiatives project of the Frankton/Dinsdale Rauawaawa Trust', Hamilton, Research and Development Unit, Te Runanga o Kirikiriroa Trust Inc.

Walker, R. (1990) Ka whawhai tonu matou: Struggle without end. Auckland: Penguin.

Welton, M. (2005). Designing the just society: A critical enquiry. Leicester: NIACE.

Withnall, A. (2010) Improving learning in later life. Oxford: Routledge.

Young M.F.D. (1971). (Ed.) Knowledge and control: New directions for the sociology of education. London: Collier-Macmillan Publishers. 